\title{
A Study Of The Effects Of Contaminated Water On Women Of Shanty Town
}

\author{
Aliyah Ali \\ Women's Studies \\ University of Karachi \\ \& \\ Muhammad Nadeemullah \\ Department of Social Work \\ University of Karachi
}

\begin{abstract}
In today's world many environmental hazards are made due to dangerous human activities. Industrialization and urbanization both are responsible for the destruction of environment. Pollution caused by human activities can be controlled but due to fragile environmental policies and lack of implementation on environmental laws it is increasing day by day. Issue of contaminated water also needs serious attention. Humans have active relationship with environment. Due to multiple roles women perform in a society she has a closer relationship with the environment. She is responsible for fetching water, cooking food, cleaning of household and sanitation activities. Therefore any problem with the quantity or quality of water impact women directly. Lack of clean drinking water is one of the major cause of morbidity and mortality. The objective of this study is to find out the effects of contaminated water on women's health in an urban slum area of Karachi.

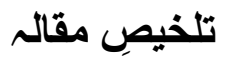

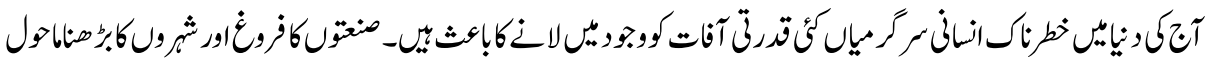

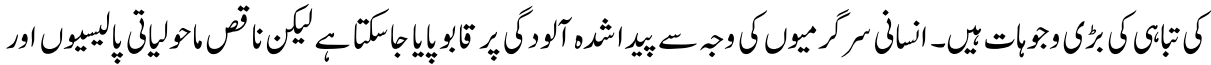

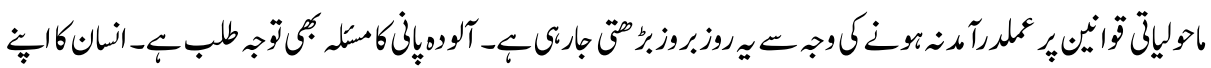

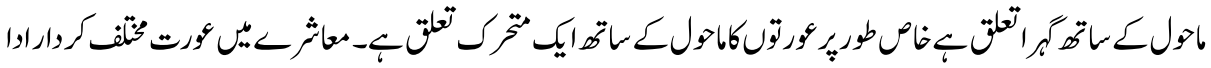

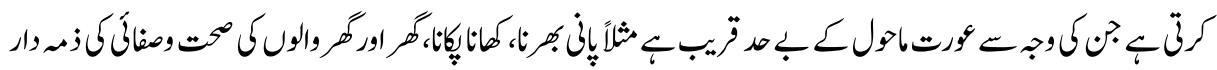

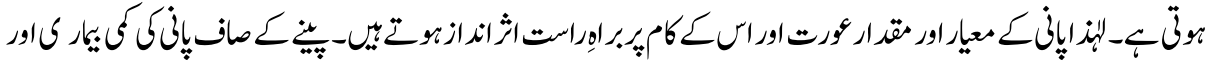

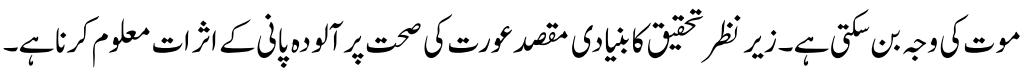

In today's world many environmental hazards have appeared due to dangerous human activities. Out of these activities the two most prominent are industrialization and urbanization, both responsible for the destruction of environment. Due to industrial activities and increasing migration many health problems are created. In the name of 
development these problems are ignored as the conventional concept of development thought to be so holy that these issues are often avoided by Governments especially in the third world. To fulfil the basic requirements of life people are involved in such activities without thinking about the destruction of environment these activities can bring to the environment, their families and most importantly to their health.

"Environment is the circumstances, objects, or conditions by which one is surrounded. It is the complex of physical, chemical and biotic factors (as climate, soil and living things) the act upon an organism or an ecological community and ultimately determine its form and survival". ${ }^{1}$ Environment can be defined as "all the various facets that comprise our planet and its surroundings (Rodda, 1991). There are many environmental hazards which cause serious destruction. Environmental hazard is a generic term for any situation or state of events which poses a threat to the surrounding environment. There are five types of environmental hazards; chemical, physical, mechanical, biological and psychological. Pollution and natural hazards are also included in the term (Zehra, 2007).

Pollution caused by human activities can be controlled but due to changing consumption patterns, fragile environmental policies and lack of implementation of environmental laws it is increasing day by day. Issue of contaminated water is also needed serious attention. Provision of safe drinking water is highly prioritized by international community and the Goal seven of Millennium Development Goals (MDGs) has a target of provision of safe drinking water. It is important to note that 884 million people do not have access to safe drinking water worldwide. ${ }^{2}$ Role of water in the hydrological cycle is main in creating many environmental issues. Only 3 percent of the planet water is fresh water and available for human use. It is estimated that the total volume of water on the earth is 1454 million cubic kilometre. Of that 94 percent is salt water in the oceans and the remaining 6 percent forms the fresh water resources essential to life. As much as society develops it consume more water. Industry use 21 percent of global water which is an essential ingredient of manufacturing processes like chemicals, papers and textile. Many environmental issues are linked with water. It is main receiving agent for liquid waste from domestic sewage to toxic industrial waste and transports harmful pollutants (Zehra, 2007). In Bangladesh between 28 and 35 million people consume drinking water with elevated level of arsenic in drinking water. Arsenic contamination of ground water has been found in many countries including Argentina, Bangladesh, Chile, China, India, Mexico, Thailand and the United States. An estimated 160 million people are infected schistosomiasis. The disease causes tens of thousands of deaths every year mainly in SubSahara Africa and it is caused by un sanitary excreta disposal and absence of nearly sources of safe water. 1.8 million every year from diarrheal diseases including cholera; 90 percent are children under 5, mostly in developing countries. 88 percent of diarrheal disease is attributed to unsafe water supply, inadequate sanitation and hygiene. 1.2 million people die of malaria each year, 90 percent of whom are children under 5 . UN decade 2005-2015 "water for life" as the international Decade for Action and sets the 
world agenda on greater focus on water related issues. Globally about 1 billion people around the world routinely drink unhealthy water, nearly 5 million deaths yearly caused by polluted drinking water. 90 percent of waste water goes untreated into local rivers and streams in the developing countries. The NEQS established in August in 1993 in Pakistan are extremely pertinent for water quality management as they provide for targeted end of pipe standards and industrial and municipal effects and air emissions, including 32 liquid and 16 gaseous parameters (SDPI, 2006, p.274).

There are different reasons of water contamination. Intensified irrigation, dams and other water related projects contribute importantly to this disease burden. ${ }^{3}$ Activities caused by the transport sector cause surface and ground water flow, modifications as well as water quality degradation. Modifications in the flow of surface waters are caused by diversions of water flows, which contribute to flooding and soil erosion that often happens far from the place of diversions and the road itself. Groundwater is often effected by road constructions, such as drainage and embankment.

While everyone in the city is under the impression of getting pure and quality water but many don't receive it. Water usually comes from water lines by government, tube well ponds or any other reservoir. As globalization continues and the earth's natural processes transform local problem into international issues, few societies are being left un-touched by major environmental problems. In slum areas of Karachi, non availability of potable water and other environmental hazards such as wastage pollution, cause of human health especially women. Water fit for human consumption is called drinking water or "potable water". People appropriate water to supply their homes, produce food, and carry out industrial activities. Water is a finite and valuable resource; its use should be guided by economic efficiency, equity and access for all.

Provision of safe water is responsibility of the government. In case of Karachi from 1981, the Karachi Water Management Board (KWMB) was created to take responsibility for water distribution throughout the metropolitan area, and it was given enhanced powers that included distribution throughout the metropolitan area, as well as cost recovery. The operations of the KWMB never became a viable proposition, as the Board did not have a revenue base of its own and relied on the KMC for collection of the water rate, although the tariff doubled during its existence - all this while responsibility for maintenance of sewerage services remained with the $\mathrm{KMC}(\mathrm{KWSB}, 2000)$. Under the devolution plan currently being implemented, the Karachi City District Government is responsible for controlling and managing water and sanitation services. Thus, in early 2003, the KWSB became an organ of the city government and was renamed the Water and Sanitation Department (WSD). Further administrative changes are still taking place. (Govt. of Sindh, 2011). The KWSB is the key water supply agency for the city. It arranges the production of water and supplies it to the taps of consumers; 263 million gallons per day (mgd) of water are supplied from the Indus-Kalri, located 80 miles from the city, and this 
supply is facilitated through a comprehensive network of conduits and pumping stations. Karachi receives $20 \mathrm{mgd}$ from Lake Haleji, $5 \mathrm{mgd}$ from Dumlottee wells and $100 \mathrm{mgd}$ from the Hub River, and all are peri-urban sources. There are various reasons for the continuing water shortages and poor levels of service. The KWSB system experiences leakage and thefts from its network, amounting to 30-35 per cent of the total supply. Leakage is the result of inappropriate management and poor maintenance of the system, incongruent external development of streets in the city that cause damage to the network, sub-standard quality of construction, and even deficiencies. At the same time, haphazard city growth and densification have contributed to a rise in water demand. New neighbourhoods are being added to the cityscape without a corresponding increase in the water supply. Inner-city areas have increased in density, giving rise to acute water shortages. Squatter settlements have sprung up in peri-urban areas, thus increasing the cost of a piped supply because of their distance from existing water mains. Settlements located at the end of the network receive a very low level of service, since a large amount of the water allocation has already been removed, legally or illegally ( Ahmed \& Sohail, 2003). In Karachi infectious disease and death is the result. The reasons of such happening were containment due to waste water i.e. industrial waste, pesticide, and sewage. People are forced to drink un-safe water.

The state of environment affects the behaviour and life style of people to great extent. The first need is shelter which if inadequate in size, designs or robustness is hazardous to health. Due to this a high accident rate, overcrowding, increased risk of infections, mental stress, in adequate water supply and sanitation, noise pollution, indoor air pollution and intra familial violence is caused. Women have an active relationship with the environment. She has multiple roles in which primary role is related to household activities. She is responsible for fetching water and fuel for house-hold use. Lack of water and sanitation causes morbidity and mortality. Women are usually responsible for waste management and sanitation training, home and family hygiene. They are at high risk of exposure to water and sanitation related diseases (Rodda, 199.p.88).

To study all these issues of women and water use in the study is based on following objective.

\section{Objective of the Study}

The purpose of the study is to find out the effects of poisonous water on women's health along with the socio-economic conditions of people living in squatter settlements.

\section{Methodology}

The research had been conducted in Karachi, NIPA Chowrangi Katchi Abadi had selected for the study. People from different ethnicities live in this area were facing 
severe health problems. It is a quantitative research based on 100 women interviews selected through simple random sampling. Through a pre structured questionnaire these women were interviewed.

Table No. 1

Who Supplied Water in your Area?

\begin{tabular}{|l|c|c|}
\hline Who supplied water & Frequency & Percentage \\
\hline Government & 60 & $60 \%$ \\
\hline Own & 40 & $40 \%$ \\
\hline Total & 100 & $100 \%$ \\
\hline
\end{tabular}

Mostly respondents said that Government supplied water to their area.

Table No. 2

Quality of Water

\begin{tabular}{|l|c|c|}
\hline \multicolumn{1}{|c|}{ Quality of water } & Frequency & Percentage \\
\hline Hygienic & 60 & $60 \%$ \\
\hline Satisfactory & 30 & $30 \%$ \\
\hline Dirty & 10 & $10 \%$ \\
\hline Total & 100 & $100 \%$ \\
\hline
\end{tabular}

Majority of respondents told that they thought that water supplied to them is hygienic which shows their unawareness and lack of knowledge about hygiene.

Table No. 3

Apply any Precautions before Using Water

\begin{tabular}{|l|c|c|}
\hline Apply any Prevention & Frequency & Percentage \\
\hline Yes & 12 & $12 \%$ \\
\hline No & 88 & $88 \%$ \\
\hline Total & 100 & $100 \%$ \\
\hline
\end{tabular}

Majority of respondents don't employ any precaution before using the water. Generally women in katchi Abadis uneducated that's why they don't know much about the necessary precautions.

Table No. 4

Do you Face any Side Effects in Terms of Death and Illness?

\begin{tabular}{|l|c|c|}
\hline Face any Side Effects & Frequency & Percentage \\
\hline Yes & 45 & $45 \%$ \\
\hline No & 55 & $55 \%$ \\
\hline Total & 100 & $100 \%$ \\
\hline
\end{tabular}

$55 \%$ of respondents don't think that water make any side effects and $45 \%$ of respondents said they are suffered from the bad quality of water. 
Table No. 5

Common Diseases of the Area

\begin{tabular}{|l|c|c|}
\hline Common diseases & Frequency & Percentage \\
\hline Malaria & 13 & $13 \%$ \\
\hline Fever & 18 & $18 \%$ \\
\hline Motion & 21 & $21 \%$ \\
\hline Pain in abdominal & 23 & $23 \%$ \\
\hline Vomiting & 12 & $12 \%$ \\
\hline Other/None & 13 & $13 \%$ \\
\hline Total & 100 & $100 \%$ \\
\hline
\end{tabular}

According to this data diseases are common in this area. By keeping in view the socio-economic conditions of these people it can be presumed that due to poverty and illiteracy these people access the basic health facilities nor have knowledge about basic hygiene.

Table No. 6

Who is More Affected?

\begin{tabular}{|l|c|c|}
\hline Who is more affected? & Frequency & Percentage \\
\hline Women & 18 & $18 \%$ \\
\hline Men & 2 & $2 \%$ \\
\hline Children & 80 & $80 \%$ \\
\hline Total & 100 & $100 \%$ \\
\hline
\end{tabular}

Children are more vulnerable to these diseases especially malaria is more in children. Globally malaria causes death of many children. This also shows negligence of Government towards people's health.

Table No. 7

Does the Skin Affected by Diseases or Rashes?

\begin{tabular}{|l|c|c|}
\hline Does the Skin Affected & Frequency & Percentage \\
\hline Yes & 80 & $80 \%$ \\
\hline No & 20 & $20 \%$ \\
\hline Total & 100 & $100 \%$ \\
\hline
\end{tabular}

Majority of respondents also complained about skin infections due to contaminated water. 
Table No. 8

Health Facilities Available in the Area

\begin{tabular}{|l|c|c|}
\hline Availability of health facilities & Frequency & Percentage \\
\hline Yes & 30 & $30 \%$ \\
\hline No & 70 & $70 \%$ \\
\hline Total & 100 & $100 \%$ \\
\hline
\end{tabular}

Majority of respondents said that they do not have health facilities in the area. Government should provide health facilities to this area to improve health conditions and also start health awareness campaigns.

\section{Case Study}

Bashi lived in squatter settlements near NIPA Chowrangi. She was married in the age of 18 years with her parents consent. She belongs to a family where an exchange marriage Wattah Sattah was very common. Bashi was engaged to her cousin before she was born so she was married to Ghulam Muhammad son of maternal uncle. Bashi told that before marriage she lived in Larkana city. She also said that they had land in the Larkana but after marriage her quarrel began with her in-laws so her husband decided to move to Karachi. In this particular squatter settlement people illegally occupied Government land. They were on rent and the rent money was $800 \mathrm{Rs}$. They lived in one room hut (Jhonpri). There is no washroom in the hut. They used their owner's washroom. They also gave rent for washroom which was $100 \mathrm{Rs}$ and also paid bill for drinking water brought from the owner's residence. Official water line was present in the owner's hut. Bashi told that drinking water was not hygienic. She complained about the abdominal pain and vomiting. She looked very sick. Bashi said that she throw garbage outside her hut because there was no garbage collection system. Bashi worked as Masi (domestic help) in the nearby society homes. Her husband is a laborer and bears the expenses of home. Bashi also said that due to her illness she had to take leave from her job.

Surprisingly Bashi was satisfied with the environment and prepared to spend whole life here. She said that they could not afford house rent that's why they lived in the hut. They lived quiet satisfactory life according to her. Bashi also complained about traffic pollution and fire wood (used for cooking) which caused headache and eye infection respectively. Her children were affected by vomiting and abdominal pain.

\section{Discussion}

Environment is a very important issue. It is a fact that humans build environment but there are also other actors responsible for the environment control and protection. The role of government is very contradictory as the slum of Karachi comes under Sind Katchi Abadi Authority. People lived in NIPA Chowrangi Katchi Abadi were facing many social, economical and health problems. The area also becomes central of criminal 
activities. Women of this area were oppressed and exploited due to poverty and male dominancy. Usually males were not engage in employment and women were working as domestic help called 'Masi' or did embroidery at homes. Many women with their children were seen begging on streets. Illiteracy was common. The supply of water in the area was by government but there were unawareness about the quality of water. Still due to they were not using any method to purify it. Usually on media public service messages are shown such as boiling of water or filtration but it is not a practice especially in low income groups. Boiling is an expensive method for poor because they buy wood or any other fuel to cook food which cost them enough leaving no choice for further use of fuel for boiling drinking water. The most common disease appeared as abdominal pain which was expected water born disease and they notified that the most effectives are the children. The environmental conditions were also affecting their lives. They had to struggle against diseases, infections and every sort of pollution. Contaminated water caused many diseases and deaths in this particular area. Many women and children were unwell due to this contaminated water but did not get any treatment. Malaria and pain in abdominal was common in women and children. Contaminated water was also affecting the reproductive health of women and causes infections.

In conclusion the importance of basic needs and its linkage to women in production and reproductive roles need attention because for a healthy society we need healthy persons. Along with that government need to take effective policy measures for provision of housing, clean drinking water and sanitation otherwise we continue living in sick environment affecting people behaviour, life style in general and women in particular.

\section{End Notes}

1. http://www.merriam-webster.com/dictionary/environment

2. http://www.un.org/millenniumgoals/pdf/MDG_FS_7_EN.pdf

3. http://www.who.int/water-sanitation-health/publications/factsfigures04/eu/

\section{References}

Ahmed, Noman \& Sohail, Muhammad, (2003) Alternate water supply arrangements in peri-urban localities: awami(people's) tanks in Orangi township, Karachi, Environment and Urbanization 2003 15: 33, p.34 http://eau.sagepub.com/content /15/2/33.full.pdf

Government of Sindh,(2001), Sindh Local, Government Ordinance, Government of Sindh, Karachi.

KWSB (2000), Karachi Water and Sewerage Board:Basic Facts - 2000, KWSB, Karachi 
KWSB (1997),Karachi - Water Supply and Sewerage: Basic Facts, KWSB, Karachi.

Rodda, Annabel (1991) Women and the Environment, Zed books Ltd, London

SDPI, (2006) Sustainable Development: Bridging the Research/ Policy Gaps in Sothern

Contexts, Vol. I, Environment, SDPI, Oxford, Islamabad

Zehra, Syeda Mah-e-Jabeen, (2006-07) A Study of the Spread of Diseases in Women's of Shanty Town /Slum Areas Due to the Environmental Hazards \& Quality of Water, M.A thesis, Centre of Excellence for Women's Studies, University of Karachi

Dr. Aliyah Ali is Co-operative Teacher in the Centre of Excellence for Women's Studies, University of Karachi.

Dr. Muhammad Nadeemullah is Assistant Professor in the Department of Social Work, University of Karachi. 